\title{
УДК 332.363
}

\section{SCIENTIFIC AND METHODOLOGICAL FUNDAMENTALS OF LAND \\ MANAGEMENT OF THE TERRITORIES OF THE UNITED TERRITORIAL COMMUNITIES}

Dorosh A., postgraduate student

E-mail: doroshandriyl@ukr.net

\section{Institute of Land Management of NAAS of Ukraine}

This article analyzes the scientific and methodological principles of land management of the territories of the united territorial communities, identifies the existing problems in the management of territorial and spatial development of territorial communities. It is established that land management is an important tool for land use management of territorial communities.

A logical-semantic model of land use management is proposed, which offers an updated definition of the object and subject of management of spatial development. The object of management is considered to be the spatial system, which consists of dimensions, resources, processes, structures and development goals, and acts as a basis for sustainable land use. We propose to consider the management of sustainable land use as a subject of management with certain methods and functions. It is substantiated that land management, which is a continuous process, is the link that has a sufficient set of tools to combine the subjects and objects of land use management.

In the process of research, the scheme of realization of process of spatial planning is developed and the lacks of this process are allocated. It is proposed to move away from complex and divided into land management and urban planning documentation system of spatial development of UTC and move to a three-tier system of planning documents at the local level, which creates the preconditions for effective management of spatial development of community land use.

Key words: land management, decentralization, united territorial community, land use management, spatial development, planning

Problem statement. United territorial communities in Ukraine need highquality planning for their own spatial development, but are often unable to do so. The system of spatial planning at the local level in Ukraine is divided into urban planning and land management documentation.

Urban planning documentation at the local level consists of three planning documents, namely the general plan of the settlement, detailed plan and zoning [9]. 
According to Article 25 of the Law on Land Management, only this law defines an exclusive list of land management documentation. In our opinion, at the local level the following planning documents are relevant:

- land management projects for landscaping for urban needs;

- land management projects for landscaping of settlements;

- land management projects for the organization of the territory of land shares (units);

- land management projects for the privatization of lands of state and communal agricultural enterprises, institutions and organizations;

- land management projects that provide ecological and economic justification of crop rotation and land management;

- land management projects to establish (change) the boundaries of administrative-territorial units;

- land management schemes and feasibility studies for the use and protection of lands of administrative-territorial units;

- land management projects for the organization and establishment of boundaries of nature reserves, other environmental, health, recreational, historical, cultural, forestry, water fund lands and water protection zones, restrictions on land use and their regime-forming objects [8].

As a result, there is a significant accumulation of planning documentation at the local level. The results of our analysis of the Law on Land Management indicate that most land management documents solve specific current problems and are not able to independently form concepts or strategies for community development. It should be noted that only land management schemes and feasibility studies for land use and protection of administrative-territorial units are capable of forming a concept or strategy, but their name clearly states that they are developed exclusively for administrative-territorial units, therefore they are not relevant for territorial communities, except when the boundaries of the community and the administrative district coincide, but then the documentation will be ordered the raion (district) 
council and not by community council. This can be a source of conflict at the local level.

Urban planning documentation is also developed mainly for administrativeterritorial units, mostly for individual settlements, as well as for districts at the local level. The most common urban planning document at the local level is the general plan of the settlement, which aims primarily to plan the development of settlements to provide labour resources for industrial or agricultural production in a planned economy, which struggles to function in case of private land ownership.

Although the legislation governing the spatial planning system in Ukraine has been repeatedly updated, the system itself and, most importantly, the methodology for its implementation remain essentially Soviet. There are several reasons for this, namely: redundancy and imperfection of planning tools; the attachment of these instruments to the system of administrative-territorial units, which has not been revised either after the declaration of independence or within the framework of decentralization of power in recent years. So we are dealing with the administrativeterritorial system and planning tools of the USSR, which were effective in the era for which they were created.

The purpose of the article is to identify the negative aspects of the spatial planning system in Ukraine and the imperfections of the planning process itself, to simplify and improve the spatial planning system in Ukraine and to propose a model of community land use planning.

Main material. Realizing the importance of institutionalizing the planning process at the local level, we first focus on what it is. This process is a set of legal, social, economic, ownership, organizational and management tools that are designed to promote rational land use [6, p. 14]. That is why our proposals are to institutionalize a simplified three-tier system of land use planning at the local level (Fig. 1). In our opinion, it should consist of the following planning documents: 1) community spatial development concept; 2) the spatial arrangement plan of the community; 3) detailed plan of the territory. 


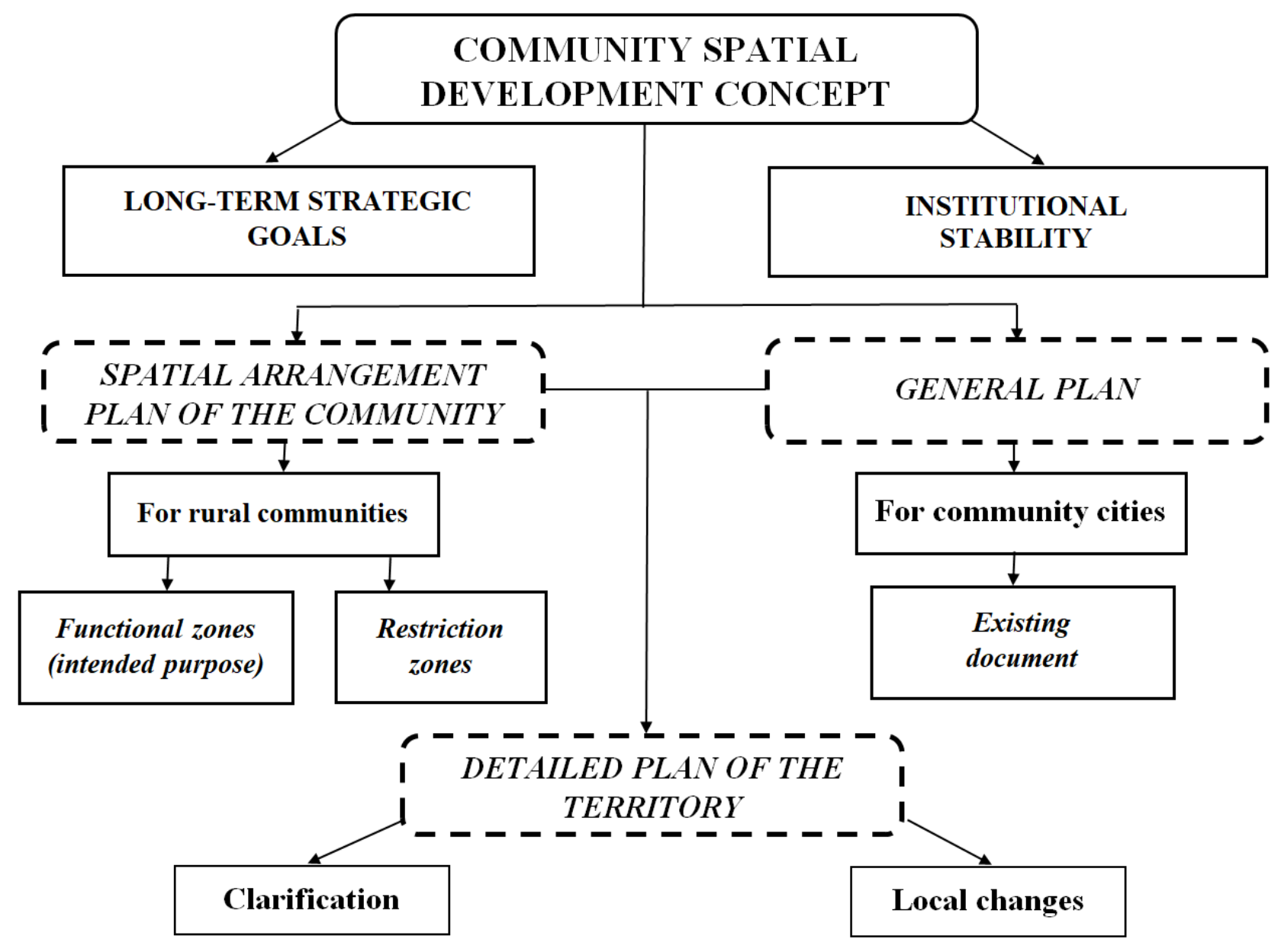

Fig. 1. Three-level system of planning documents at the local level [2]

Analysing the international experience, we state that the proposed hierarchy of spatial planning tools is really able to ensure the institutionalization of an effective process of spatial development management at the local level. First, it is important to form a concept of community development and define long-term strategic goals for its development. Their fixation, formalization and guarantee of institutional sustainability are the tasks of the first level planning document, namely the concept of spatial development of the community. This tool is extremely important, but it can be effective only if local governments and local residents understand and recognize the goals and objectives set by them. Therefore, we believe that it should not be mandatory for communities, because its development without realizing its significance will lead only to a waste of local budget funds.

The next document that should be mandatory for the development is the spatial arrangement plan of the community. We believe that this document is the most important among our proposed, because its task is to determine the functional areas, 
which in turn serve as a basis for determining the intended purpose, as well as the formation of zones of restrictions on land use. This document is important for the formation of the legal regime of land use in the community. It is envisaged that this tool will strengthen and fix the goals and objectives defined by the concept of spatial development. An important aspect is that this land management document also provides an opportunity to form the urban landscape of rural areas, i.e. to establish urban planning restrictions and to form the legal basis for the development of local infrastructure. Due to the appearance of such documents, the need to develop master plans of settlements for rural communities disappears. The general plan of the settlement, as the town-planning documentation is expedient only in the citiescommunities. It is also possible to establish and change the boundaries of settlements within the framework of the development of this planning document. Given the fact that it is the land management documentation, as well as the fact that the planning of rural areas is mainly the task of land managers, it is these specialists who should develop it.

In the future, in order to make local changes and to form new arrays for construction, we propose to use the existing detailed plan of the territory, the development of which is not mandatory. The proposed changes should be reflected in the Laws of Ukraine 'On Land Management' and 'On Regulation of Urban Development'.

However, there are also opposing beliefs in professional circles. Not all experts agree with the expediency of simplifying and combining urban planning and land management documentation into one planning system. For example, O. Dorosh argues that community development planning should be reflected in the following planning documentation: 1) Spatial development plan of the land use system in the community; 2) The plan of borders of administrative-territorial division of the councils entering into the territory of the united territorial community; 3) Plan of the existing territorial zones of restrictions (encumbrances) in the use of land within the community; 4) Development plan (land zoning by their categories and types) of land use within the community; 5) Plan of land management of the settlement [5, p. 107]. 
We have already mentioned above that these documents are developed by specialists in land management and urban planning. However, the planning process in general is quite complex and accordingly we offer a scheme that gives a basic idea of the planning process of spatial development (Fig. 2), and also simplifies the decisionmaking process of the spatial planning process and its further implementation.

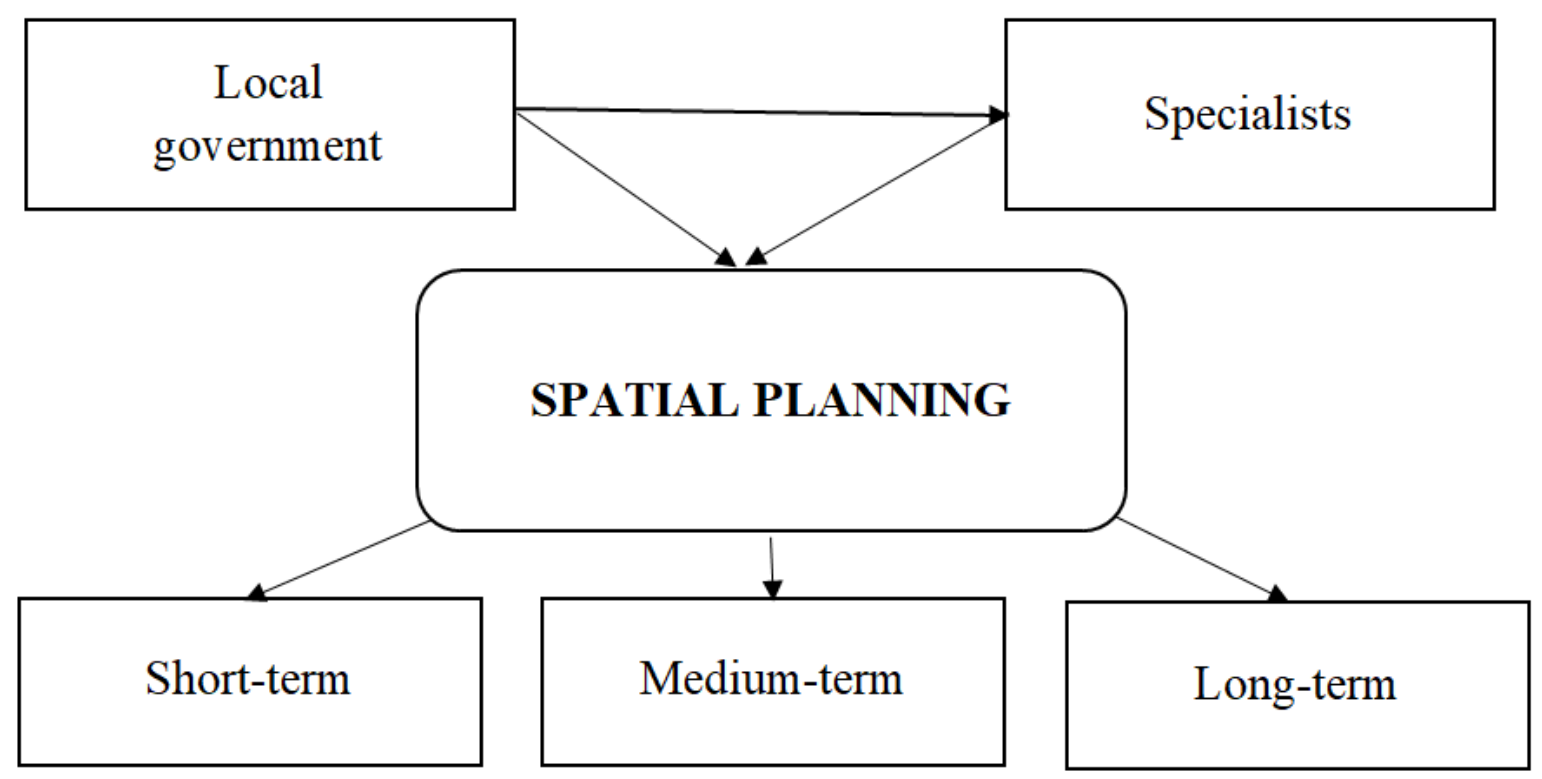

Fig. 2. The scheme of implementation of the spatial planning process [2]

Spatial planning at the local level is the task of local government. But it should be noted that they do not develop planning documents on their own, they only form tasks for specialists who develop these planning documents. But the implementation of measures planned by specialists falls on the shoulders of local government. However, local governments face the following set of problems: 1) both local authorities and local residents often do not realize the importance of forming strategic goals of community development, to achieve which it is necessary to build a planning process and further implement planned activities; 2) not every specialist is able to carry out comprehensive planning of spatial development of the community; 3) inability of specialists to convince local authorities and local residents of the need for a comprehensive approach to spatial development planning; 4) the predominant realization of short-term needs of individuals in spatial planning.

Spatial planning is seen as a comprehensive task in the short, medium and long term, which involves and affects many people. Although usually people believe that 
planning decisions do not affect them. Short-term planning is the most common practice, which involves the implementation of several decisions by certain stakeholders. When it comes to the implementation of strategic objectives of community development, spatial planning is carried out much less often and for a long period. Land use planning is a political issue at the local level. With this in mind, the strategic decisions of community development require the support of the majority of its residents and readiness to implement the planned measures.

We emphasize that through the system of tasks it is possible to realize the goal of managing sustainable community development. In particular we propose the following tasks:

- creation of a well-established community resettlement system;

- implementation of functional zoning (agriculture, urban development, recreation, etc.) of communities territory with mandatory regulation of their use, giving the prerogative of the ecological network;

- patronizing the development of cooperation in various fields (agriculture, industry, recreation, etc.);

- promoting the development of the infrastructure network;

- solving problems related to energy supply and energy saving;

- making efforts to improve the living environment of people in the community.

So, a logical-semantic model which reveals the essence of land use planning within the community is proposed (Fig. 3).

The model reflects the functions of land management of communities on the basis of sustainable development, which include: organization and regulation of spatial planning, monitoring and control. Priority positions are occupied by the planning function, which significantly contributes to the development of land use, and further regulation, analysis and control come into force. The monitoring, reporting and statistics functions play a significant role in this regard. 


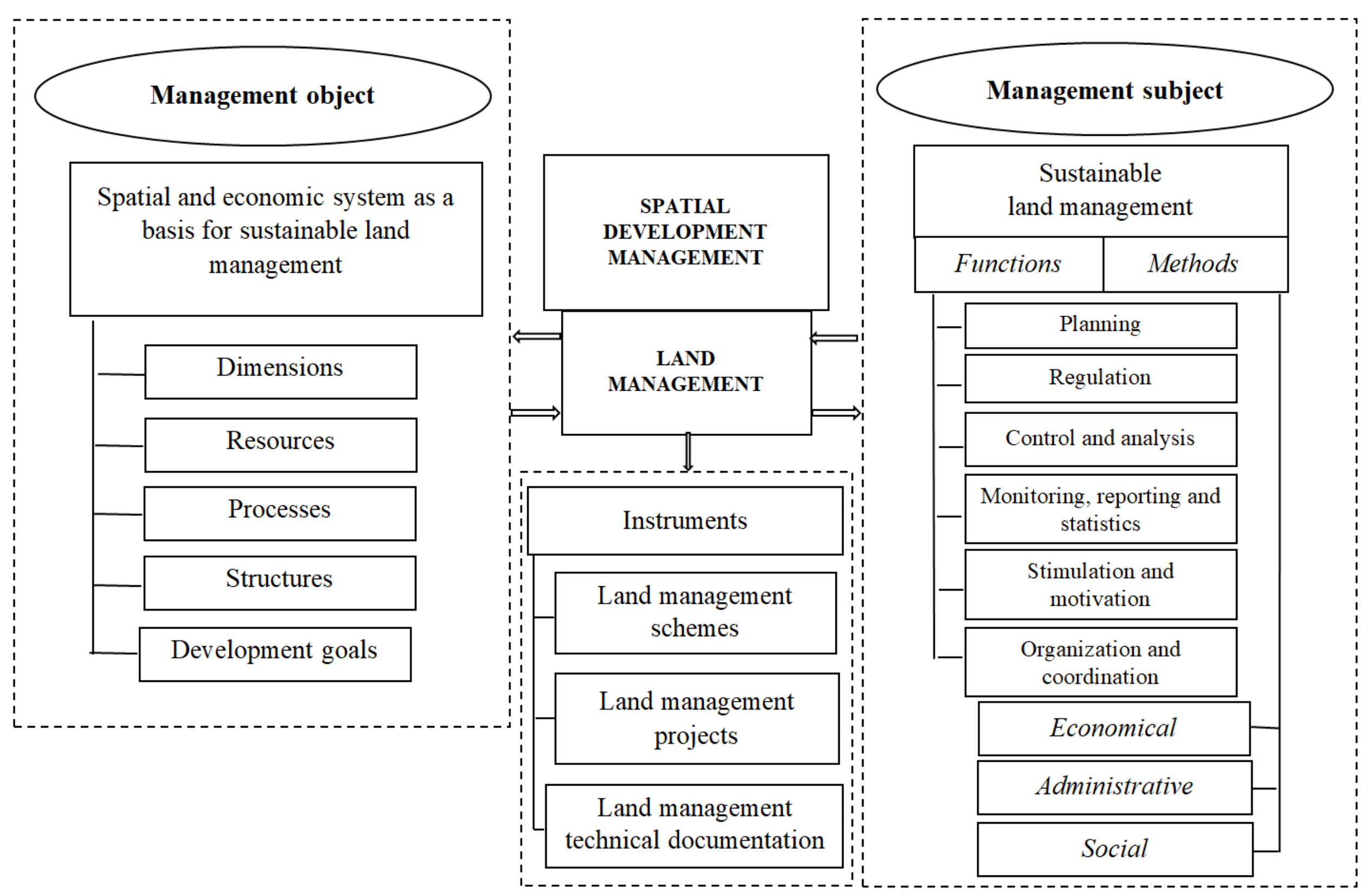

Fig. 3. Logical and semantic model of community land use planning [2] 
The process of community land use planning and implementation requires well-established organization and coordination, and the success of the implementation of the envisaged measures depends on another management function - the involvement of all participants in this process, their stimulation and motivation.

To implement the envisaged measures, it is important to focus on the choice of methods of community land use management on the basis of sustainable development, which will contribute to the achievement of strategic planning goals. It is a question of creation of an economic basis for participants of process (personal, group and public interests) at a combination of means and tools for the purpose of the decision of problems [7]. As for administrative management methods, they ensure the influence of the subject of management on the object according to the power subordination scheme [1].

To ensure the appropriate socio-psychological climate of the community, its individual members use social management methods, which are aimed at the development of the individual, his social protection and harmonization of social relations, etc. [10].

Regarding the object of management (spatial and economic system) as a basis for sustainable land management, planning activities for which are carried out, it contains dimensions, processes, resources and provides development goals.

Land management is the defining process, because it is carried out continuously by combining objects and subjects of management in land use planning. Through land management tools, sustainable land management entities have the opportunity to carry out planning activities for management objects. In scientific circles there is an opinion that 'the substance of land management efficiency, especially territorial, lies in the economics of space use' $[4$, p. 71$]$, and it is also considered that the means of land management comprehensively substantiate the decisions made, which are provided by the action program [3, p. 33].

Conclusions. The conceptual negative aspects of both the spatial planning system in Ukraine and the planning process itself have been identified. An updated model of institutionalization of the spatial planning system in the community is 
proposed. Upgrading the system will get rid of the accumulation of planning tools at the local level in Ukraine. Accordingly, we consider it appropriate to move to a threetier system of spatial planning at the local level. In this case, we will have the following hierarchy of planning documents: 1) community spatial development concept; 2) the spatial arrangement plan of the community; 3) detailed plan of the territory.

Our proposed logical and semantic model of the implementation of the process of spatial planning of community land use clearly outlines the subjects and objects of land use management, while defining land management as the process that combines these objects and subjects. Conceptual spatial land use planning determines the narrative and trajectory of the spatial development of the community for a long period, respectively, the quality, integrity and coverage of planning are keys to the sustainable development of community land use.

\section{References}

1. Administratyvni metody [Administrative methods]. Navchalni materialy onlain. 2020.

URL: https://pidru4niki.com/1280052845142/pravo/administrativni metodi

2. Dorosh A. (2020). Ecological and economic bases of land use planning in the context of territorial and spatial development. URL: https://nubip.edu.ua/sites/default/files/u145/dis_dorosh.pdf

3. Dorosh O. (2011). Ekolohobezpechnyi ekonomichnyi royvytok silskykh terytorii I terytorialnyi zemleustrii [Ecologically safe economic development of rural areas and territorial land management]. Zemlevporiadnyi visnyk, 7, 30-33.

4. Dorosh O. (2010). Ekonomichna teoriia vykorystannia prostoru i terytorialnyi zemleustriy [Economic theory of land use and territorial land management]. Problemy formuvannia ta otsinky efektyvnosti funktsionuvannia suchasnykh zemlehospodarskykh system: International scientific conference. Kyiv. RVPS Ukrainy NAN Ukrainy. 28. October 2010. 69-72. 
5. Dorosh O. (2018). Land management planning of the land use system in territorial communities: organizational-institutional aspect. Influence of bioeconomy on spatial development of territories: International scientific and practical conference. Kyiv, 25-28.

6. Dorosh O. (2013). Metodolohichni zasady formuvannia instytutsionalnoho seredovyshcha terytorialnoho planuvannia zemlekorystuvannia $\mathrm{v}$ Ukraini [Methodological bases of formation of institutional environment of territorial planning of land use in Ukraine]. Land management, Cadastre and Land Monitoring. $1-2,13-18$

7. Ekonomichni metody upravlinnia [Economic management methods]. Navchalni materialy onlain. 2020. URL: https://pidru4niki.com/10310208/turizm/ekonomichni_metodi_upravlinnya

8. Zakon Ukraiiny "Pro zemleustrii" [Law of Ukraine "On Land Management”]. Vidomosti Verkhovnoii Rady Ukrainy. 2003. № 36. 282. Available at: https://zakon.rada.gov.ua/laws/show/858-15\#Text

9. Zakon Ukraiiny "Pro rehuliuvannia mistobudivnoii diialnosti” [Law of Ukraine "On Regulation of Urban Development"]. Vidomosti Verkhovnoii Rady Ukrainy. 2011. № 34. 343. URL: https://zakon.rada.gov.ua/laws/show/ 3038-17\#Text

10. Sotsialni metody upravlinnia [Social management methods]. Bezkoshtovna biblioteka pidruchnykiv. 2020. URL: http://www.infolibrary.com.ua/books-text-5527.html

\section{Список літератури}

1. Адміністративні методи // Навчальні матеріали онлайн. 2020. URL: https://pidru4niki.com/1280052845142/pravo/administrativni_metodi

2. Дорош А.Й. Еколого-економічні основи планування землекористування в контексті територіальнопросторового розвитку. 2020. URL: https://nubip.edu.ua/sites/default/files/u145/dis_dorosh.pdf 
3. Дорош О.С. Екологобезпечний економічний розвиток сільських територій і територіальний землеустрій. Землевпорядний вісник. 2011. № 7. С. 30-33.

4. Дорош О.С. Економічна теорія використання простору i територіальний землеустрій. Проблеми формування та оцінки ефективності функціонування сучасних землегосподарських систем: Міжнар. наук. Конф., м. Київ, РВПС України НАН України, 28 жовт. 2010 р.: тези доп. Київ, 2010. C. 69-72.

5. Дорош О.С. Землевпорядне планування системи землекористувань в територіальних громадах: організаційно-інституційний аспект. Вплив біоекономіки на просторовий розвиток територій: зб. матеріалів доп. учасн. Міжнар. наук.-практ. конф. Київ, 2018. С. 104-107.

6. Дорош О.С. Методологічні засади формування інституціонального середовища територіального планування землекористування в Україні. Землеустрій, кадастр і моніторинг земель. 2013. № 1-2. С. 13-18

7. Економічні методи управління // Навчальні матеріали онлайн. 2020. URL: https://pidru4niki.com/10310208/turizm/ekonomichni_metodi_upravlinnya

8. Про землеустрій: Закон України. Відомості Верховної Ради України (BBP). 2003. URL: http://zakon3.rada.gov.ua/laws/show/858-15

9. Про регулювання містобудівної діяльності: Закон України. Відомості Верховної Ради України (ВВР). 2011. URL: https://zakon.rada.gov.ua/laws/show/ 3038-17\#Text

10. Соціальні методи управління // Безкоштовна бібліотека підручників. 2020. URL: http://www.info-library.com.ua/books-text-5527.html

Дорош А.Й.

НАУКОВО-МЕТОДИЧНІ ЗАСАДИ ЗЕМЛЕУСТРОЮ ТЕРИТОРІЙ ОБ'ЄДНАНИХ ТЕРИТОРІАЛЬНИХ ГРОМАД 
У даній статті проаналізовано науково-методичні засади землеустрою територій об' 'еднаних територіальних громад, визначено наявні проблеми 8 управлінні територіально-просторовим розвитком територіальних громад. Встановлено, щуо землеустрій є важливим інструментом управління землекористуванням територіальних громад.

Запропоновано логічно-смислову модель управління землекористуванням, щุo пропонує оновлене визначення об 'єкту та суб 'єкту управління територіально-просторовим розвитком. Об'єктом управління вважаємо територіально-просторову систему, що складається з вимірів, ресурсів, процесів, структур та иілей розвитку, та виконує роль базису сталого землекористування. Пропонуємо управління сталим землекористуванням вважати суб' 'ктом управління з визначеними методами та функиіями. Обтрунтовано, що землеустрій, який є безперервним процесом, є саме тією ланкою, яка володіє достатнім набором інструментів для поєднання між собою суб 'єктів та об'єктів управління землекористування.

У процесі дослідження розроблено схему здійснення процесу просторового планування та виокремлено недоліки, характерні для цього процесу. Запропоновано відійти від складної, розгалуженої та розділеної на землевпорядну та містобудівну документацію системи планування просторового розвитку ОТГ та перейти на трирівневу систему планувальних документів на місцевому рівні, щзо створює передумови ефективного управління просторовим розвитком землекористування громади.

Ключові слова: землеустрій, децентралізація, об 'єднана територіальна громада, управління землекористування, територіально-просторовий розвиток, планування

Дорош А.И.

НАУЧНО-МЕТОДИЧЕСКИЕ ОСНОВЫ ЗЕМЛЕУСТРОЙСТВА ТЕРРИТОРИЙ ОБЪЕДИНЕННЫХ ТЕРРИТОРИАЛЬНЫХ ОБЩИН 
В данной статье проанализированы научно-методические основь землеустройства территорий объединенных территориальных общин, определень сущуествующче проблемь в управлении территориальнопространственным развитием территориальных общин. Установлено, что землеустройство является важным инструментом управления землепользованием территориальных общин.

Предложено логически-смысловую модель управления землепользованием, что предлагает обновленное определение объекта и субъекта управления территориально-пространственным развитием. Объектом управления считаем территориально-пространственную систему, состоящую из измерений, ресурсов, процуессов, структур и изелей развития, которая выполняет роль базиса устойчивого землепользования. Предлагаем управления устойчивым землепользованием считать субъектом управления, который имеет определенные методыл и функции. Обосновано, что землеустройство, которое является непрерывным процессом, является именно тем звеном, которое обладает достаточным набором инструментов для соединения между собой субъектов и объектов управления землепользованием.

В прочессе исследования разработана схема осуществления прочесса пространственного планирования и выделены недостатки, характерные для этого процесса. Предложено отойти от сложной, разветвленной $u$ разделенной на землеустроительную и градостроительную документацию системь планирования пространственного развития ОТГ и перейти на трехуровневую систему планировочных документов на местном уровне, что создает предпосылки эффективного управления пространственным развитием землепользования общчиньл.

Ключевые слова: землеустройство, децентрализация, объединенная территориальная община, управление землепользования, территориальнопространственное развитие, планирование 